Technological University Dublin ARROW@TU Dublin

\title{
Multinationality of UK firms - a longitudinal study based on sales and subsidiaries data
}

\author{
Pearlean Chadha \\ Technological University Dublin, pearlean.chadha@tudublin.ie \\ Jenny Berrill \\ Trinity College Dublin, Ireland
}

Follow this and additional works at: https://arrow.tudublin.ie/buschacart

Part of the Business Administration, Management, and Operations Commons, and the Business and Corporate Communications Commons

\section{Recommended Citation}

Chadha, P. and Berrill, J. (2021), "Multinationality of UK firms - a longitudinal study based on sales and subsidiaries data", Multinational Business Review, Vol. 29 No. 2, pp. 281-299. https://doi.org/10.1108/ MBR-03-2020-0065

This Article is brought to you for free and open access by the School of Accounting and Finance at ARROW@TU Dublin. It has been accepted for inclusion in Articles by an authorized administrator of ARROW@TU Dublin. For more information, please contact arrow.admin@tudublin.ie, aisling.coyne@tudublin.ie, gerard.connolly@tudublin.ie.

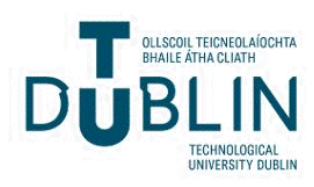




\title{
Multinationality of UK firms - a longitudinal study based on sales and subsidiaries data
}

Study based on sales and subsidiaries data

\author{
Pearlean Chadha \\ College of Business, Technological University Dublin, Dublin, Ireland, and \\ Jenny Berrill \\ School of Business, Trinity College Dublin, Dublin, Ireland
}

\begin{abstract}
Purpose - This paper aims to contribute to the regionalisation-globalisation debate in international business (IB) by providing a longitudinal analysis of firm-level multinationality. The analysis uses a unique hand-collected data set of both accounting (sales) and non-accounting (subsidiaries) data. The percentage of foreign sales is also used as an additional measure of multinationality.

Design/methodology/approach - This paper categorises constituent firms of the Financial Times Stock Exchange 350 index over an 18-year time period from 1998 to 2015. Firms are categorised using the multinationality classification system developed by Aggarwal et al. (2011). The paper also conducts an industrial analysis across ten industries.

Findings - The evidence shows increasing multinationality over time that suggests a "trans-regional" operational strategy rather than a global or regional one. The results also show that UK firms are more multinational based on subsidiaries than sales. This contradicts the traditional stages theory of internationalisation where firms first expand sales, then subsidiaries. While some support for triad regions is found, there is also evidence of firm-level operations expanding beyond the triad regions of North America, Asia and Europe to non-triad regions such as Africa, Oceania and South America. The industrial analysis shows that non-service firms are more multinational than service firms.

Originality/value - To the best of the authors' knowledge, this is the first paper to provide an in-depth longitudinal analysis of the geographical dispersion using both sales and subsidiaries data for UK firms. This paper provides a unique perspective on the regionalisation-globalisation debate in IB and presents evidence contrary to traditional stages theories of firm-level internationalisation.
\end{abstract}

Keywords Multinational corporations (MNCs), Internationalisation patterns,

Trans-regionals, UK MNCs

Paper type Research paper

\section{Introduction}

Traditional theories of internationalisation outline a gradual process through which firms increase their international involvement and commitment over time. Johanson and Vahlne (2006) suggest that firms do not have an exact path of internationalisation but that some internationalisation paths are more likely than others. Most studies on firm-level internationalisation find that firms are increasing in multinationality over time (Oehler et al., 2017). Leading multinational corporations (MNCs) had on average 64\% foreign sales, $62 \%$

The authors are grateful to the anonymous reviewer and Editor in Chief, Chang Hoon Oh, for their invaluable guidance and insightful suggestions and comments, which have improved significantly the quality of this article. 
MBR 29,2

foreign assets and 60\% foreign employees in 2015 (UNCTAD, 2015). The existing literature on firm-level multinationality and the process of internationalisation followed by firms suggest that there is no one prescribed path followed by all. Firms may internationalise slowly or rapidly and may follow different paths based on a global or a regional strategy (Chetty and Campbell-Hunt, 2003; Chetty et al., 2014). Previous studies investigating the multinationality of firms typically focus on one measure of multinationality and are conducted at one point in time (Oehler et al., 2017; Rugman, 2003). Some of these crosssectional studies use measures of multinationality such as foreign sales percentages, foreign capital flows, foreign taxes and number of employees. Some recent studies undertake a longitudinal study of firm-level internationalisation using accounting measures of multinationality such as sales and assets (Berrill and Hovey, 2018; Oh et al., 2019).

With these studies in mind, this paper undertakes a longitudinal analysis of firm-level multinationality of the Financial Times Stock Exchange (FTSE) 350 index constituent firms over an 18-year time period from 1998 to 2015. All existing studies focus exclusively on accounting data [exceptions include Oh (2009) and Rugman and Oh (2011, 2013)]. This paper argues that accounting data is limited in that it fails to capture the full extent of geographical dispersion of firms' activities. Firms also tend to disclose the same geographic segments for each of the accounting variables (Berrill, 2015). The use of subsidiaries data helps to overcome these shortcomings and provides a more robust, in-depth measurement of firm-level internationalisation. This study extends existing work by Berrill and Hovey (2018) by using both accounting (sales) and non-accounting (subsidiaries) data. A unique hand-collected data set on the geographical location of each firms' subsidiaries each year is compiled. This data set captures the geographic dispersion of firm-level sales and subsidiaries. Using the classification system introduced by Aggarwal et al. (2011), each firm is categorised based on the location of their sales and subsidiaries. The percentage of foreign sales to total sales is used as an additional measure to test the robustness of our findings. Our analysis is an extension to existing cross-sectional studies (Rugman et al., 2012; Oehler et al., 2017) as the 18-year time period provides a detailed investigation on how the internationalisation pattern of firms progresses over time. No study exists to the best of our knowledge that conducts a longitudinal analysis on firm-level internationalisation using the geographic scope of both accounting (sales) and non-accounting (subsidiaries) data. The use of subsidiaries data puts forth an alternative measure for a firm's upstream activity that captures investments beyond the firm's accounting books. The analysis in this paper adds to the regionalisation vs globalisation debate in international business (IB) by investigating if firms internationalise to geographically close regions or further a field.

This study also undertakes an industrial analysis over the 18-year time period. Firms are categorised into ten industries using FTSE International's Industry Classification Benchmark System and the changing patterns of multinationality are compared across industries over time. UNCTAD's (2015) World Investment Report notes the importance of the services sector in today's global business environment given its elevated levels of foreign direct investment (FDI). Kundu and Lahiri (2015) note that studies on the multinationality patterns of service sector multinationals are sparse. The lack of academic research in this area calls for a comparative longitudinal analysis of service and non-service sector firms, which this paper also undertakes.

The results based on location of sales, location of subsidiaries and foreign sales percentage, show that firm-level multinationality is increasing over time. There is little evidence that firms are regional in their sales and subsidiaries operations, with a growing number of firms becoming global. Most firms in the data set have trans-regional sales and subsidiaries with the focus remaining consistently on the triad regions of North America, Europe and Asia. This suggests that the triad regions as proposed by Rugman and his co-authors continue to be 
relevant. There is, however, evidence that there is an increasing presence of firms in Africa and South America. This puts forth evidence that firm operations are becoming more geographically dispersed into new regions. The analysis also shows that firms are more multinational based on subsidiaries than sales, which demonstrate the dynamic multidimensional aspect of the internationalisation process. It also contradicts the traditional stages of internationalisation theory proposed by Dunning (1993), which suggests that firms initially have sales abroad and ultimately progress to setting up subsidiaries. This is an important finding as most studies focus on sales data and do not capture this investment as a facet of multinationality. These results highlight the importance of using both accounting and nonaccounting data to gain a complete analysis of firm-level multinationality. The industrial analysis shows that basic materials and oil and gas are the most multinational sectors whereas utilities is the least, based on both measures of sales and subsidiaries. There is also evidence that non-service firms are more multinational than service firms in each year.

The remainder of this paper is structured as follows. Section 2 gives an overview of existing literature. Section 3 describes the data and methodology used to categorise firms and analyse their degree of multinationality. Section 4 details the results of the analysis. Section 5 presents a discussion and our main conclusions.

\section{Review of the literature}

Most papers analysing the regionalisation vs globalisation of firms use the four-fold typology developed by Rugman and Verbeke (2004). They classify firms' sales as home-region oriented, host-region oriented, bi-regional and global. The spread of sales is measured across the broad triad regions of North America, Europe and Asia. Home-region oriented firms have more than $50 \%$ of sales within the home region of triad, host-region oriented have more than $50 \%$ of sales in another triad region, bi-regional firms have more than $20 \%$ in two other regions but less than $50 \%$ sales in the home region and global firms have more than $20 \%$ of sales in all triad regions. Their findings suggest that the world's largest firms in 2001 are not global but rather focus only on their home-regions. Rugman and Brain (2003) find that the 20 most multinational firms on the Fortune 500 list are mainly home-region based in their operations.

These studies use sales data as a measure of multinationality i.e. focus on downstream activities from a supply chain perspective. From an IB perspective, downstream activities relate to distribution and upstream activities examine production (Mentzer et al., 2001). Collinson and Rugman (2008) follow the same classification system using sales (downstream) and assets (upstream) data for Japanese multinationals in 2003. They find that a majority of firms average over $80 \%$ of their sales and assets in their home-region. Rugman et al. (2009) put forth similar evidence for some of the largest North American firms using sales and assets data from 2000 to 2006 . They find that over $85 \%$ of firms in their sample have supply chains in the North American region. Banalieva and Santoro (2009) examine the regionalisation argument by measuring the geographic spread of sales of 701 companies from 28 emerging markets between 2000 and 2006. They find that most firms have domestic operations, followed by intra-regional, then global. Oh and Contractor (2012) also use accounting variables (sales and assets) for US firms from 1998 to 2004. They categorise firms as proximate, distant and global based on their expansion into the triad regions. They find that $62 \%$ of the firms follow a distant expansion by expanding into Europe and Asia. Rugman et al. (2012) analyse the international competitiveness by using the sales and assets data of Fortune Global 500 firms in 1998 and 2008. Their findings suggest an increase in firm-level international involvement over the time period. They also suggest that most multinationals operate sales and assets within their home-region. Oh et al. (2019) study the paths and geographic scope of international expansion of firms across different industries. 
MBR 29,2
They find that internationalisation paths and geographic spread of upstream (assets) and downstream (sales) activities are home-region oriented. Many firms operate beyond the home-region but few firms are global with operations across all triad regions. They also find that over time, firms are likely to achieve larger geographic scope for their downstream activities than their upstream activities.

Other studies use macro-economic data to measure the level of international involvement of MNCs. Makhija et al. (1997) suggest that the international trade flow data shows that globalisation levels of industries vary across different countries and the industries are becoming increasingly multinational over time. They examine import and export data for 27 industries from 5 countries from 1970 to 1986 and find that European industries are more global in comparison to US or Japanese industries. Ghemawat (2003) examines the FDI and flow of knowledge, labour and capital over a 100-year time period and notes that there is a state of semi-globalisation based on economic evidence. He states that markets are neither completely isolated nor integrated, and we fall between these two extremes. Flores and Aguilera (2007) examine the foreign investment activities of US multinationals in 1980 and 2000. They find that US MNCs have geographically expanded their international activities in 2000 relative to 1980 . They also find evidence that the investments have gone beyond the triad regions of Asia, North America and Europe. Dunning et al. (2007) find support for the regionalisation theory using macro-economic data. However, they propose that micro-data or firm-level data should be used in combination with country-level data to measure MNC activity.

Some studies incorporate foreign subsidiary information while measuring levels of multinationality. Ietto-Gillies (2001) combines firm-level subsidiary data with FDI data for 664 of the world's largest firms based on market capitalisation and finds that Germany has the highest number of trans-national firms, followed by Switzerland, Japan, Sweden and the USA. The dispersion of firm operations in different countries appears to be size and sector specific. Oh (2009) examines 227 large European firms listed in the Fortune Global 500 from 2000 to 2006 and finds no evidence that their operations are becoming increasingly geographically dispersed. The study uses both scale and scope metrics to analyse international involvement of firms. He uses foreign sales and foreign assets as scale measures. Scope measures used are the number of subsidiaries and number of countries a firm has subsidiaries in. He concludes that European MNCs tend to focus on their home region rather than the global market. Rugman and Oh (2011) also apply similar scale and scope metrics to test the regional nature of US firms from 2000 to 2007 . A total of $25 \%$ of sales and assets of US firms take place abroad and there is some increase in these measures over time. They suggest that using the foreign sales to total sales ratio appropriately captures the multinationality. However, using scope metrics that count the number of countries in which firms have subsidiaries or the number of foreign subsidiaries do not take into account the geographic spread of foreign involvement and the size of the countries. These count measures tend to be an incorrect and inaccurate measure of multinationality. Rugman and Oh (2013) confirm the home regional focus by analysing the geographic distribution of sales and assets for the world's largest firms between 2000 and 2007. They also use scale and scope measures based on Oh (2009).

While many studies support regionalisation, there are studies that put forth evidence to the contrary. Osegowitsch and Sammartino (2008) test the regional nature of MNCs by modifying thresholds in the Rugman and Verbeke (2004) classification. They find that by relaxing the thresholds, many firms are home-region oriented. However, substantially more firms report sales in two triad regions other than their home region. Asmussen (2009) proposes an index to investigate the regional or global orientation of large MNCs. He 
combines intra- and extra-regional sales expansion in an orthogonal index objectively scaled, and controls for differences in country sizes. He finds that large MNCs tend to follow a home-region oriented internationalisation path, though with strong national biases. Arregle et al. (2009) support the semi-globalisation perspective for 1,076 Japanese MNCs over 1996-2001 and highlight the merits of a regional level analysis of foreign subsidiary activity. Berrill (2015) studies 1,289 firms from G7 countries using sales and subsidiary data from 2005. She concludes that many firms are in fact trans-regional or global, suggesting that globalisation is not a myth and shows that firms are moving towards a more transregional and global strategy. O'Hagan-Luff and Berrill (2016) categorise 396 US firms and find that the number of geographic regions where firms report sales increased between 1996 and 2010. They also note that firms with sales in all 6 geographic regions, that is global firms, account for only a maximum of 8 out of 396 firms over the time period studied.

Oehler et al. (2017) investigate the constituent firms of UK, USA, Germany and France in 2012 using foreign sales, foreign tax payments and number of employees in foreign countries. They find that UK and French firms exhibit the highest degree of internationalisation based on all three measures. Brennan et al. (2018) categorise 88 firms from the Fortune 500 from 1990 to 2010, using sales data. Their findings based on Aggarwal et al.'s (2011) classification system suggest that firms follow a "semi-globalisation" strategy where an increasing number of firms are trans-regional, and the number of domestic firms decline over time. Yip (2002), Gupta et al. (2008), Regnér and Zander (2014) and Berrill and Hovey (2018) also find that firms tend to follow a global strategy rather than a regional one to maximise competitiveness. The geographic diversification or the scope of a firm has been at the centre of strategy research as well (Peng and Delios, 2006). The research has evolved over the years and there is increasing focus on the geographic scope of a firm across the world. While the majority of studies use sales or other accounting variables as a measure of multinationality, many argue that the narrow perspective is not sufficient in capturing the richness of the international activities of multinationals (Clark and Knowles, 2003; Clark et al., 2004). Thus, we use two distinct measures of multinationality to conduct a longitudinal analysis of the geographic spread of sales and subsidiaries of UK firms.

\section{Data and methodology}

Our data set uses the constituent firms from the FTSE 350 index. The accounting data of foreign sales and its geographic breakdown is obtained from Thomas Reuters World scope. The non-accounting (subsidiaries) data is hand collected for each firm in each year from Who Owns Whom books published by Dun and Bradstreet. For the industrial analysis, this paper uses the FTSE International's Industrial Benchmark System, which classifies firms into ten industries - basic materials, consumer goods, consumer services, financials, health care, industrials, oil and gas, technology, telecommunications and utilities. This classification system is used extensively in the existing literature (Bekaert et al., 2011; Marcelo et al., 2013; Donadelli and Persha, 2014; Mullen and Berrill, 2015).

This analysis uses the location of sales and subsidiaries data to measure firm-level multinationality of FTSE 350 for each year from 1998 to 2015. These measures represent both accounting and non-accounting data. Additional accounting variables are not used in the analysis such as assets, operating income, capital expenditure and depreciation. As noted by Berrill (2015), in most cases, firms list the same geographic segments for each of the accounting variables. Therefore, we use hand-collected subsidiaries data in our analysis as the use of additional accounting variables will add little to the analysis. Rugman and $\mathrm{Oh}$ (2011) put forward two ways of measuring multinationality of firms, using scale metrics and scope metrics. Scale measures include foreign to total sales and foreign to total assets. They 
MBR 29,2 find that using the count of the number of countries in which firms have foreign subsidiaries as a scope measure is unsatisfactory. The count of the number of countries does not take into account the geographical spread of the subsidiaries across the world. Verbeke et al. (2016) highlight that the existing studies focus on sales as downstream activities but are unable to take into account the increasing cross-boundary upstream MNC activities in their supply chains, especially to emerging economies. This suggests that existing studies fail to measure the geographic spread of firm activities and there is scarce use of non-accounting data. Our paper fills these gaps as it emphasises the use of distinct measures of multinationality to analyse the geographic spread of a firm's downstream (sales) and upstream (subsidiaries) activities. The longitudinal classification uses the taxonomy developed by Aggarwal et al. (2011). This system measures the multinationality of each firm in each year. The extent to which a firm's operations are geographically spread is measured based on sales and subsidiaries data across six geographical regions, namely, Asia, Europe, North America, South America, Africa and Oceania. This approach is based on geography and overcomes the limitations of other regional breakdowns, based on political or economic boundaries. The classification system uses the following categories to classify each firm; domestic (D), regional (R), trans-regional (T) and global (G). Domestic (D) firms have operations only in their home country; regional (R) firms have operations only in their home region; trans-regional (T) firms have operations outside their home-region; and global $(\mathrm{G})$ firms have operations in all six geographical regions. The trans-regional category is further decomposed into T2 representing operations in two regions, T3 representing operations in three regions, T4 representing operations in four regions and T5 representing operations in five regions. Each category is given a score such that domestic firms score 0 , regional firms score 1, T2 firms score 2, T3 firms score 3, T4 firms score 4, T5 firms score 5 and global firms score 6 . Finally, annual foreign sales percentage is used as an additional measure of firm-level multinationality for each firm in each year. The following example illustrates how foreign sales used in combination with the classification captures the geographic spread of operations. In 2002, BAE Systems reports sales in all six geographical regions but the percentage foreign sales is $35 \%$. On the other hand, Green Core reports sales only in Europe in 2002 and the percentage of foreign sales outside the UK is $70 \%$. This example highlights the importance of using both measures to gain a more complete measure of multinationality as they both capture different aspects of multinationality - the total level of multinationality vs the geographic spread of operations. The sales and subsidiaries score are combined into a classification of four types of firms with different degrees of multinationality. These categories derive from a two-dimensional matrix of firm-level multinationality based on firms' trade (sales) and investments (subsidiaries) in foreign markets. These categories are purely domestic firms with both sales and subsidiaries in the home-country, firms with regional sales or subsidiaries, firms with trans-regional sales or subsidiaries and firms with global sales or subsidiaries. These measures of multinationality provide a more robust and detailed longitudinal analysis of a firm's international operations than that existing in literature to date.

\section{Results}

\subsection{Location of sales and subsidiaries}

Table 1 provides the categorisation of firms' sales data. In 1998, 30.8\% of firms were domestic firms with sales only in the UK. The proportion declines to $28.39 \%$ in 2015. Domestic firms form a relatively small percentage of the FTSE 350 index suggesting that it should not be viewed as a domestic index with no exposure to foreign markets. Regional firms with sales only in Europe rise from $7.03 \%$ in 1998 to $9.69 \%$ in 2007. The proportion 


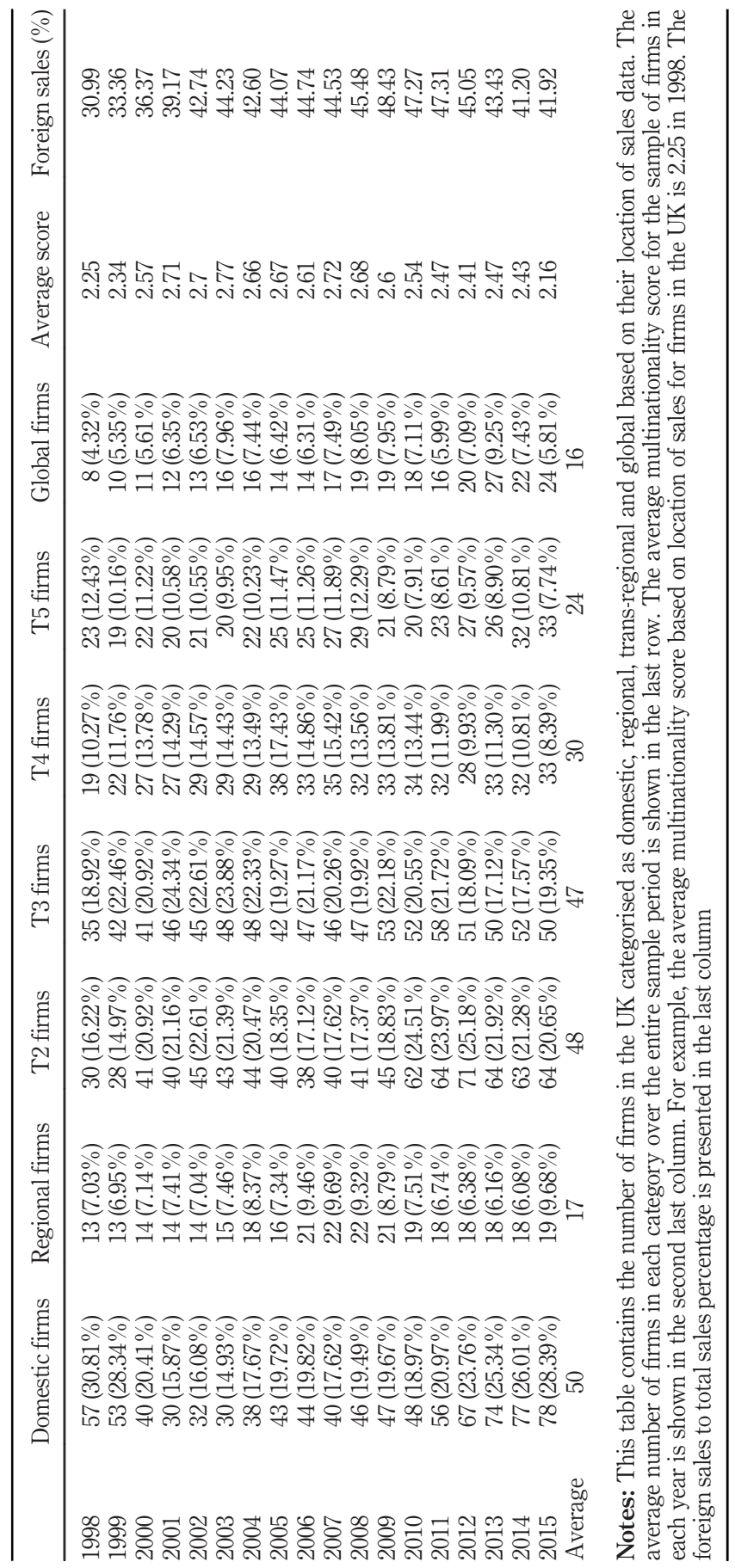

Study based on sales and subsidiaries data

287

Table 1. Classification based on sales 
MBR 29,2

decreases to $6.06 \%$ in 2014 . The average number of regional firms is 17 . The majority of firms are classified as trans-regional (T2, T3, T4 and T5). A total of $16.2 \%$ firms are classified as T2 in 1998, increasing to $25.1 \%$ in 2012 . A total of $19.9 \%$ of firms are categorised as T3 in 1998 increasing to $24.3 \%$ in 2001. In 2015, the proportion of T3 firms in the sample is $19.35 \%$. The average number of T3 firms is 47 over the time period. The proportion of T4 firms remains above $10 \%$ throughout the sample period. A total of $12.4 \%$ of firms in 1998 were categorised as T5 and $10.8 \%$ in 2014. The proportion of global firms is $4.32 \%$ in 1998 , increasing to $7.43 \%$ in 2014 , with a peak in 2013 of $9.24 \%$. The average number of global firms is 16 , a small proportion of the sample. These results show that the majority of firms are categorised as trans-regional and a small number of firms follow a regional and global strategy. These trends provide evidence of increasing multinationality over time.

The findings provide little evidence in favour of regionalisation as suggested by the many works of Rugman and his co-authors (Rugman, 2003; Rugman and Verbeke, 2004; Rugman and Oh, 2010, 2013). The findings are consistent with previous studies where regional and global firms form a small proportion of firms while the trans-regional category dominates (Berrill, 2015; O'Hagan Luff and Berrill, 2016; Chadha and Berrill, 2016; Brennan et al., 2018; Berrill and Hovey, 2018). The average multinationality score, which ranges from 0 (domestic) to 6 (global), is between 2.25 and 2.77 regions throughout the sample. This provides evidence that on average, firms have sales in two regions. Table 1 also reports the average foreign sales percentage for each year. The average for the 18-year time period is $42 \%$. The average foreign sales percentage for firms in 1998 is $30 \%$, consistently increasing until 2009 (48\%). Post the financial crisis, there is a slight fall until the end of the sample time period. Overall, the foreign sales percentage and the multinationality score based on sales shows an increasing trend over the sample period. The multinationality score increases steadily compared to the percentage of foreign sales data. For example, the average percentage of foreign sales decreases from $47 \%$ in 2011 to $41 \%$ in 2014 , whereas the change in the average multinationality score is only from 2.47 to 2.43 . This highlights the benefits of undertaking a comprehensive analysis of the dispersion of sales rather than simply analysing the changing percentage of foreign sales each year.

Table 2 presents the categorisation of FTSE 350 firms' subsidiaries data. A total of $40.12 \%$ of firms are domestic in 1998 and reduce to $30.21 \%$ in 2015 . The average number of domestic firms is 54.56 during the sample period. A total of $14.53 \%$ of firms are regional in 1998. This falls to $1 \%$ in 2006 . In 2015 , the proportion of regional firms is close to the overall average of $14.24 \%$. This suggests that firms in the UK are more focused on their home country than the home region of Europe. The majority of firms are classified as transregional with subsidiaries in $2-5$ regions. T2 firms are $15.12 \%$ of the sample in 1998 and increase to $18.22 \%$ in 2013 . In $2015,12.50 \%$ firms are categorised as T2. The average number of T2 firms is 25.94. A total of $12.79 \%$ of firms are categorised as T3 in 1998 and increase to $15.11 \%$ in 2006 . In $2015,11.11 \%$ of firms are categorised as T3. The average number of T3 firms is 20.17. In 1998, 8.72\% firms are categorised as T4, increasing to $14 \%$ in 2008. In 2015, T4 firms form $10.07 \%$ of the sample and the average number of T4 firms is 19.22. The proportion of T5 firms in 1998 is $7.56 \%$, increasing to $11.07 \%$ in 2009 . The average number of firms in this category is 14.67 over the sample period. The proportion of global firms with subsidiaries in all six regions is very low $(1.16 \%)$ in 1998 , but in the following years, it consistently increases to $15.04 \%$ in 2014 . The average number of global firms over the time period is 14.72 . The regional and global firms form a small proportion of the total sample and trans-regional firms form the majority, consistently increasing over the 18 years. These findings provide strong evidence supporting the increasing multinationality 


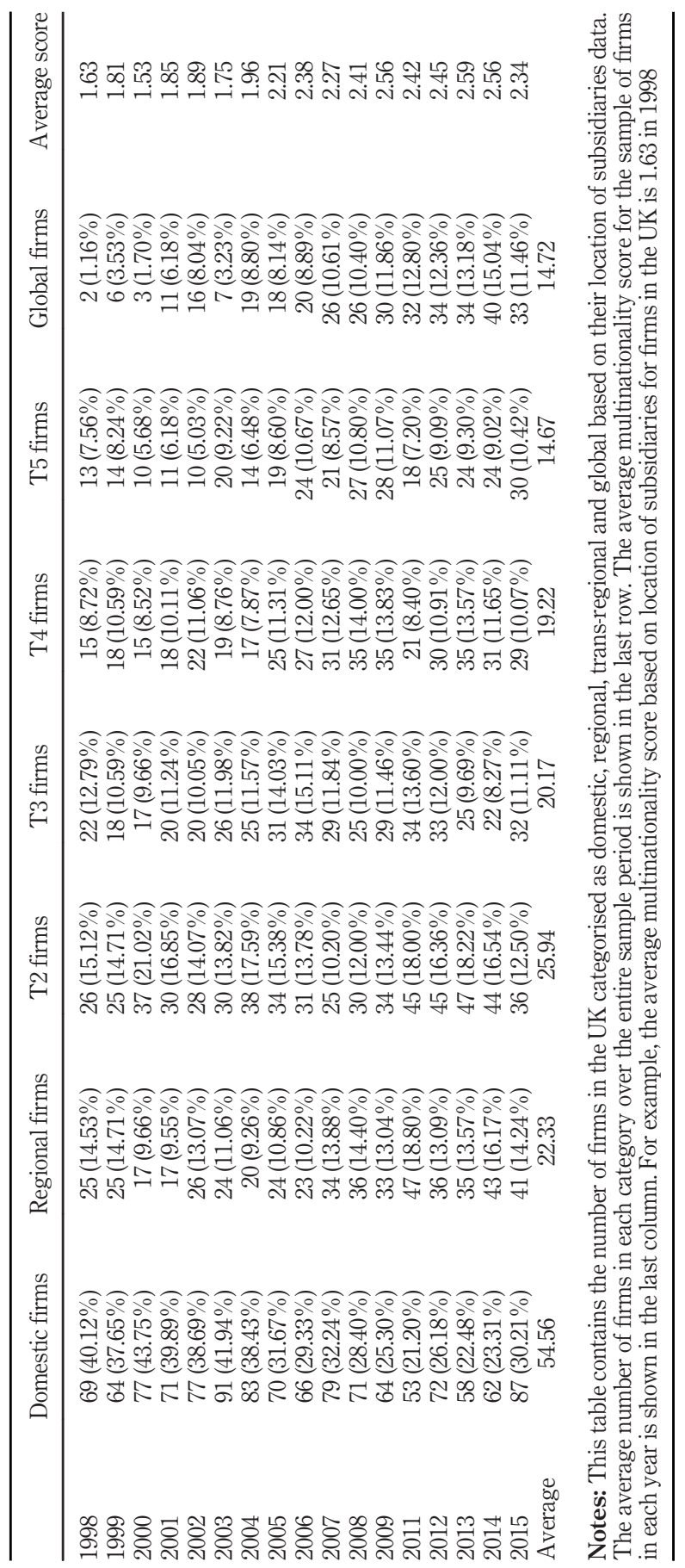

Study based on sales and subsidiaries data

289

Table 2. Classification based on subsidiaries 
MBR

29,2

290

of firms. The findings based on the measure of subsidiaries show a greater increase in the 18-year time period compared to the measure of sales.

Figure 1 compares the sales and subsidiaries measures and highlights the importance of using non-accounting data to get a complete picture of changing firm-level multinationality over time. The average number of regions firms report sales in is higher than the average for subsidiaries from 1998 to 2008. After the recession, the trend changed. Overall, the sales trend in the figure shows the static levels of multinationality scores in terms of number of regions that firms operate in. In contrast to the sales score, the subsidiaries data suggest a more dynamic and incremental nature of firm-level internationalisation over the past two decades. This implies that firms are more international in their sales than their subsidiaries before the financial crisis but are now investing more abroad. This increase in multinationality post the financial crisis is captured by the subsidiaries data. Thus, while measuring the level of multinationality, researchers should no longer rely on accounting data to provide a complete picture.

Figure 2 shows panels A and B representing the proportion of firms in each category based on sales and subsidiaries, respectively. Panel A shows the increasing proportion of T2 and T3 firms over the 1998-2015 time period. There is also evidence that the proportion of regional and global firms is small. Panel B shows the decline in the proportion of domestic firms based on subsidiaries. The global firms based on subsidiaries gradually increase from 2004 to 2015. Panels A and B also support our earlier results that the proportion of trans-regional firms dominate the sample of firms throughout the 18-year time period.

De-internationalisation of firms is a phenomenon that appears in more recent IB literature (Benito and Welch, 1997). There is some evidence of de-internationalisation. In 5 out of 18 years $(2008,2010,2011,2012$ and 2015), there is a decline in the average number of

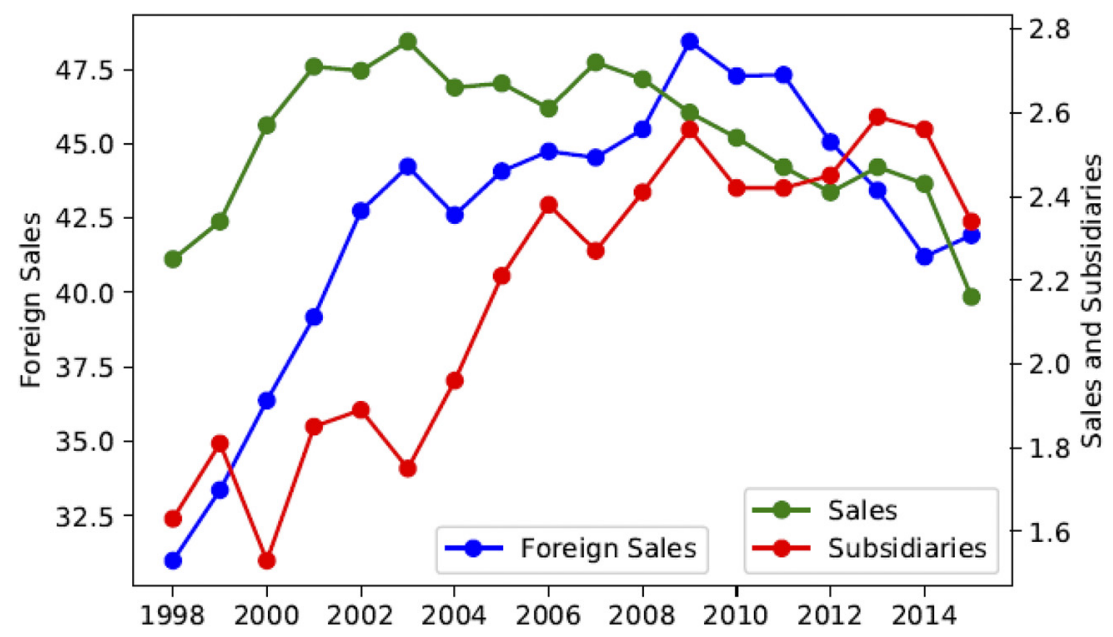

Figure 1.

Comparison of foreign sales, sales and subsidiaries
Notes: Figure 1 shows the average number of regions that firms in the sample report sales and subsidiaries and the average foreign sales percentage over the 18 year time period from 1998 to 2015. For example, in 2010 UK firms on average reported sales in 2.5 regions and subsidiaries in 2.4 regions. The average percentage foreign sales of UK firms in 2010 is $46 \%$ 


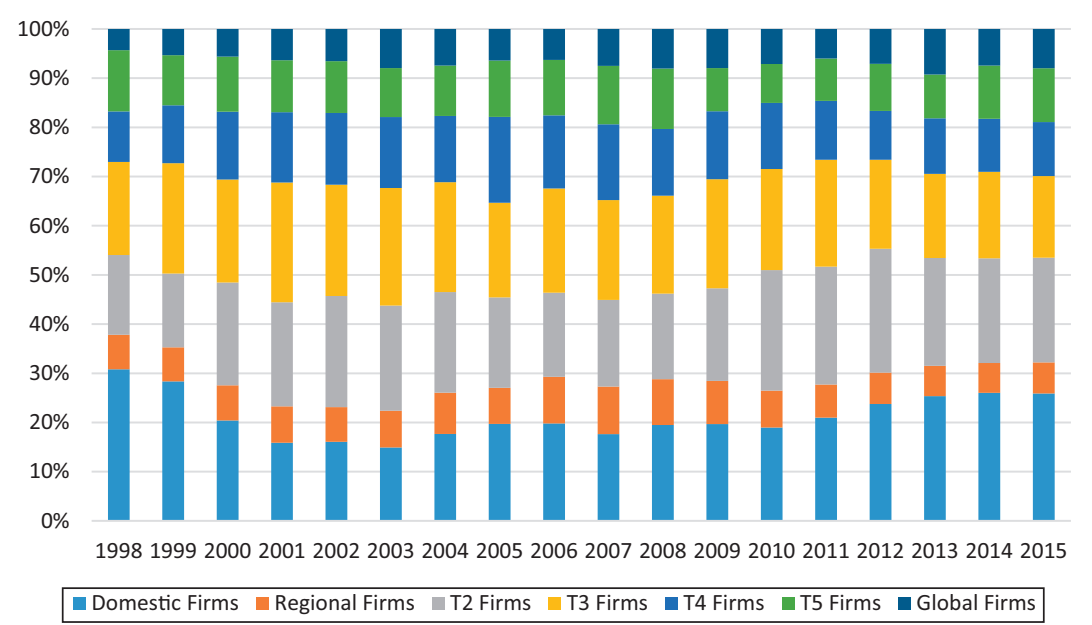

(a)

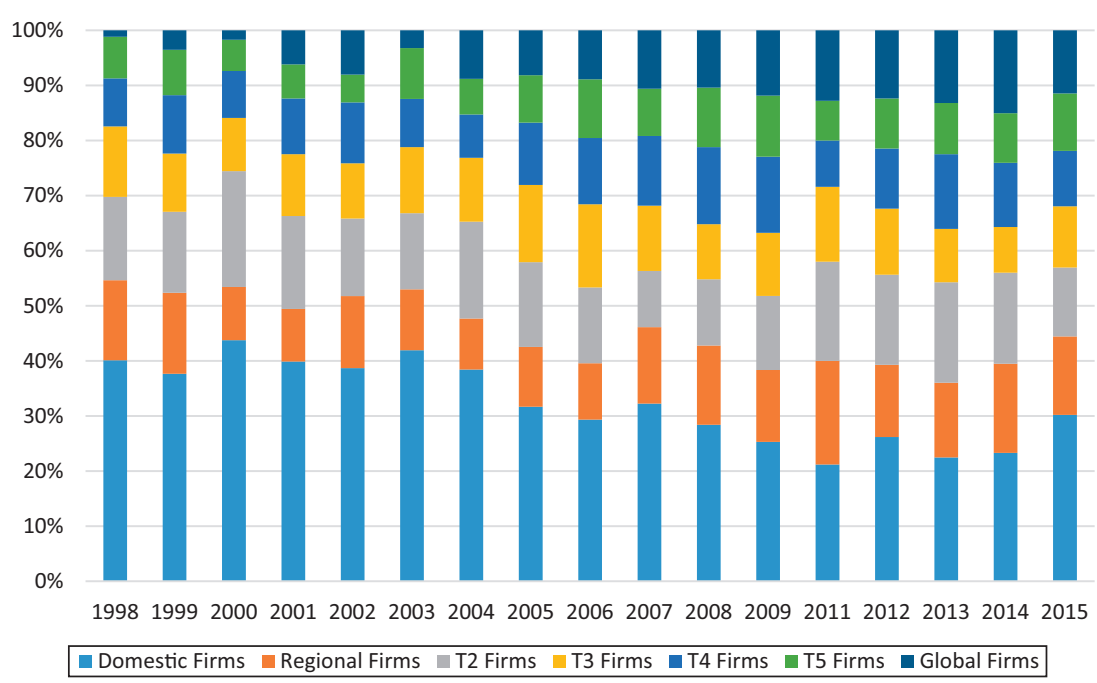

(b)

Notes: This figure shows the proportion of firms in each of the categories namely, Domestic, Regional, T2, T3, T4, T5 and Global firms. Panel A and Panel B show the distribution of firms in each year based on sales and subsidiaries data respectively. For example, in $199840 \%$ of firms in the sample are categorized as Domestic based on subsidiaries. This proportion falls to $20 \%$ in 2011
Study based on sales and subsidiaries data 291

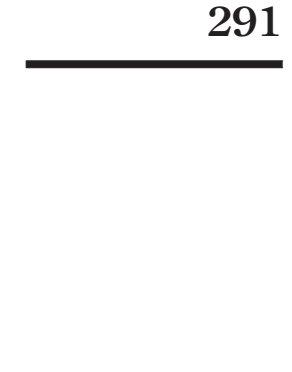


MBR 29,2

The results of the geographical analysis for firms based on location of sales and subsidiaries are presented in Table 3. The majority of UK firms have sales and subsidiaries in their home region, followed by North America and Asia, thereby highlighting evidence of the prevailing significance of the triad region (Rugman, 2003). The analysis also finds that firms with both sales and subsidiaries in South America, Africa and Oceania have increased dramatically over the time period. This is an important finding as it provides evidence that while firms operations focus on the traditional triad regions, there is a growing presence of UK firms in non-triad regions. This trend is similar for both sales and subsidiaries, although the number of firms that have subsidiaries in non-triad regions is greater than firms reporting sales in those regions. Overall, both measures of sales and subsidiaries indicate an increasing level of multinationality, with firms expanding sales from their home region to becoming trans-regional and entering new regions such as South America and Africa.

\subsection{Two-dimensional matrix classification}

Next, the sales and subsidiaries data are combined to form a two-dimensional matrix. Firms are categorised into four categories and results are presented in Table 4. The categories domestic, regional, trans-regional and global are used to measure the extent of the geographic dispersion of operations. Sales and subsidiaries are used to measure a firm's market engagement, with sales representing downstream activities and subsidiaries representing upstream activities. The number of firms with purely domestic sales and subsidiaries is $28(26.92 \%)$ in 1998 falling to $21(16.15 \%)$ in 2015 . The majority of UK firms have trans-regional sales or subsidiaries. The number of firms in the trans-regional category is $66(63.45 \%)$ in 1998 and increases to $173(75.87 \%)$ in 2011. The number of global firms forms a small proportion of the sample at the beginning of the analysis (7.69\% in 1998). However, over time, there is a consistent increase in the number of firms with global operations. In 2014, the number of global firms is $46(21.29 \%)$. The results show that firms expand their operations over time as domestic and regional firms fall in number while transregionals form a majority of the sample. The results also show that the number of firms with more geographically dispersed subsidiaries than sales is growing over time. This new facet again highlights the distinction and merit in using both sales and subsidiaries data to measure firm-level internationalisation.

\subsection{Industrial analysis}

This study uses the Industrial Classification Benchmark (ICB) system to categorise firms into 10 industries as follows: basic materials (18 firms), consumer goods (29 firms), consumer services (73 firms), financials (120 firms), health care (15 firms), industrials (64 firms), oil and gas (10 firms), technology (9 firms), telecommunications (6 firms) and utilities (7 firms). A comparison of the multinationality levels across each industry is presented in Table 5. The data set is further categorised into service (223 firms) and non-service firms (128 firms).

The most multinational industry based on sales in basic materials with an average score of 4.19 regions. This is followed by oil and gas with an average score of 3.39 regions. The least multinational industry based on location of sales is utilities with an average score of 1.70. Financials and consumer services have the highest number of firms and have an average multinationality score of 1.98 and 1.85, respectively. The sales measure is increasing on average for all industries with the exception of consumer services and health care, where the average number of regions with sales is decreasing. Results are similar based on the subsidiaries measure. Basic materials industry is the most multinational industry with an average score of 3.36. The least multinational industry based on 


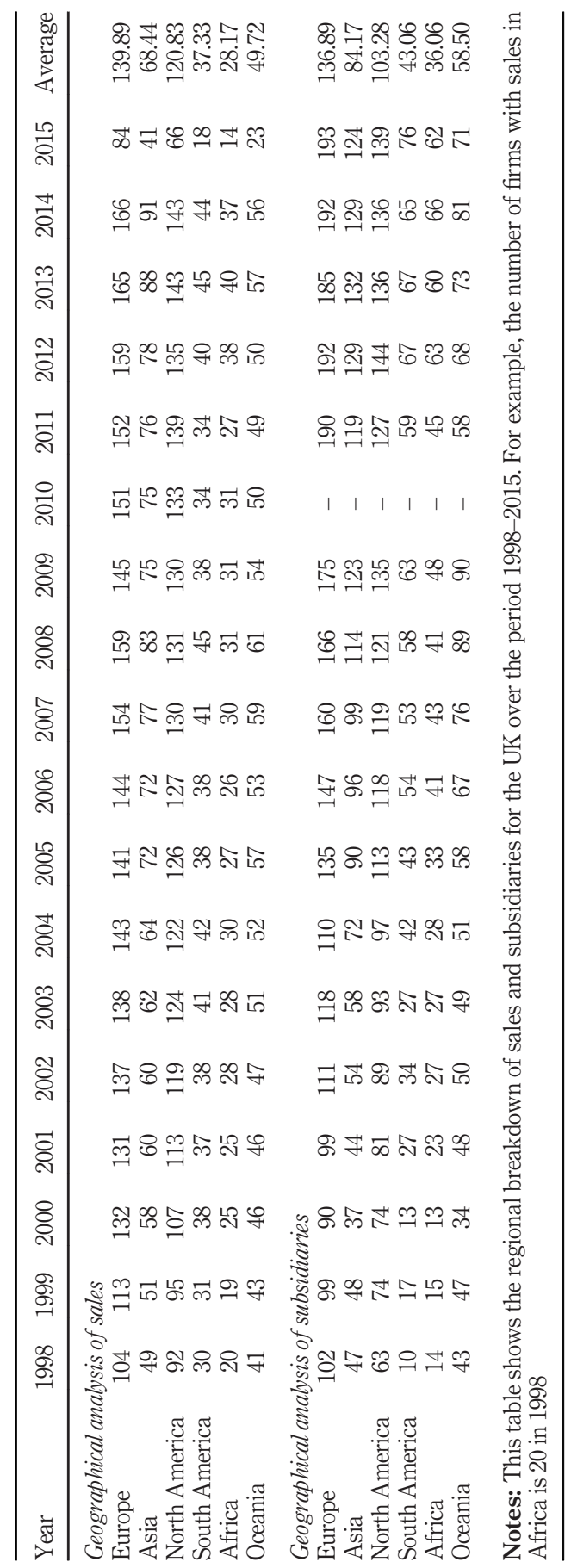

Study based on sales and subsidiaries data

293

Table 3. Geographical analysis based on sales and subsidiaries 
MBR

29,2

294

subsidiaries is also utilities with an average score of 1.81 over the sample period. The industrial analysis shows a similar level of multinationality for measures of sales and subsidiaries. However, the scores based on sales are greater than for subsidiaries. Nonservice firms are more multinational than service sector firms for the full time period. The average score of multinationality for service sector firms is 2.13 based on sales and 1.74 based on subsidiaries. The average multinationality score for non-service sector firms is 3.03 based on sales and 2.74 based on subsidiaries. The most multinational sectors are the nonservice sectors, whereas the service sectors are the least multinational.

\section{Discussion and conclusion}

This paper conducts a longitudinal analysis on the pattern of multinationality of UK firms over an 18-year period from 1998 to 2015. The firms in the sample are classified using the taxonomy of multinationality developed by Aggarwal et al. (2011). The use of accounting data (sales) and hand-collected non-accounting (subsidiaries) data provides a robust analysis of firm and industry level multinationality. This paper has strong implications for the regionalisation vs globalisation debate in IB research. Firstly, evidence of a growing "trans-regionalisation" strategy dominates the sample of UK firms. These findings are in line with many existing studies that suggest regional and global firms are few in number and there is an increase in firms pursuing a trans-regional strategy (Brennan et al., 2018; Berrill and Hovey, 2018; Oehler et al., 2017; Osegowitsch and Sammartino, 2008; Flores and Aguilera, 2007). The results, in support of increasing multinationality, provide meaningful direction to the conflicting results present in extant literature that leave the discussion on firm-level internationalisation inconclusive and often misleading. The analysis updates and extends previous studies that are either cross-sectional or use only a single metric of multinationality. There is evidence that multinationality has increased over time and only

\begin{tabular}{lcccc}
\hline & Domestic firms & Regional firms & Trans-regional firms & Global firms \\
\hline 1998 & $28(26.92)$ & $21(20.18)$ & $66(63.45)$ & $8(7.69)$ \\
1999 & $22(20.37)$ & $19(17.6)$ & $73(67.6)$ & $12(11.11)$ \\
2000 & $23(20.35)$ & $18(15.91)$ & $82(72.55)$ & $11(9.72)$ \\
2001 & $21(16.67)$ & $16(12.7)$ & $96(76.19)$ & $20(15.87)$ \\
2002 & $18(12.77)$ & $23(16.32)$ & $100(70.92)$ & $21(14.9)$ \\
2003 & $19(13.67)$ & $20(14.4)$ & $103(74.11)$ & $28(17.67)$ \\
2004 & $24(15.00)$ & $20(12.5)$ & $116(72.52)$ & $25(15.15)$ \\
2005 & $24(14.55)$ & $21(12.74)$ & $119(72.12)$ & $28(15.47)$ \\
2006 & $25(13.81)$ & $27(14.91)$ & $135(74.58)$ & $35(17.95)$ \\
2007 & $26(13.33)$ & $35(17.95)$ & $140(71.79)$ & $36(17.74)$ \\
2008 & $27(13.30)$ & $35(17.24)$ & $145(71.43)$ & $38(17.93)$ \\
2009 & $29(13.68)$ & $31(14.63)$ & $174(72.66)$ & $38(16.66)$ \\
2011 & $21(9.21)$ & $47(20.63)$ & $180(73.77)$ & $44(18.04)$ \\
2012 & $36(14.75)$ & $38(15.58)$ & $170(72.65)$ & $47(20.09)$ \\
2013 & $35(14.96)$ & $32(13.67)$ & $166(76.84)$ & $46(21.29)$ \\
2014 & $17(7.87)$ & $43(19.9)$ & $90(69.23)$ & $21(16.16)$ \\
2015 & $21(16.15)$ & $24(18.47)$ & 124 & 28 \\
Average & 24.5 & 27.6 & &
\end{tabular}

Table 4.

Classification based on two-dimensional matrix
Notes: This table shows the four categories based on the combined measure of sales and subsidiaries. These categories are purely domestic firms with sales and subsidiaries only in the UK, firms with regional sales or subsidiaries, firms with trans-regional sales or subsidiaries and firms with global sales or subsidiaries. For example, there are 28 firms with purely domestic operations in 1998 and they fall to 17 firms in 2014 


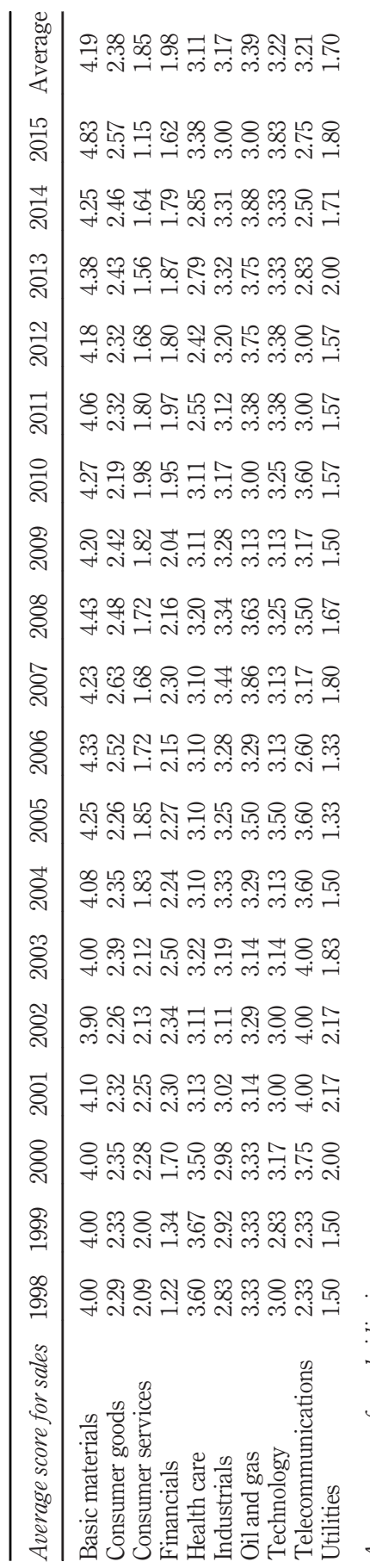

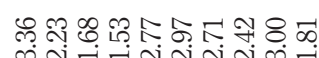
ণ่ งั่

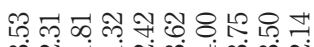

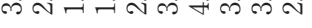

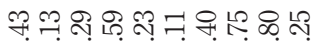
ง $ง$ ง

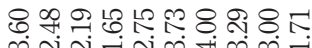
ต v

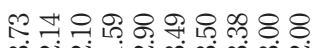

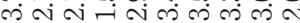

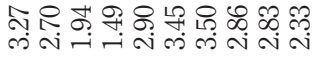<smiles>CCCC1CCC1</smiles>

운 \&

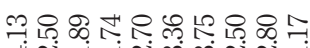

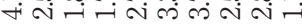
$\infty$
$\cdots$
$\cdots$

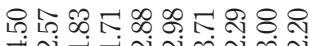

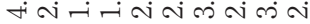

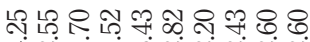
+

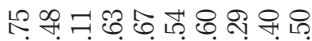
๓่ง

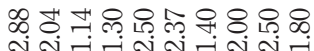
는

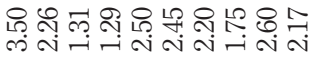

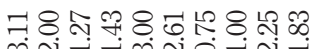
ค1

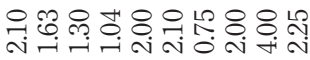

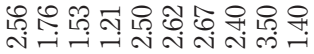

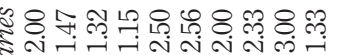

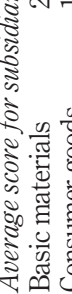

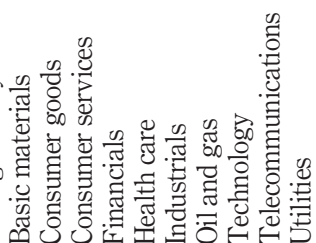

$\because$ ง

華宁

न्न

$\infty \infty$

ชิ กิ

ชั ชั

$8 \%$

ง

공

는음

ลิ่

ำ

ปู

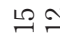

고ำ

กู

กิ

जi

กี่

놩ㄴㅇㅇㅇ

ㄱำ

年

ง

กุร

ง

$\infty$

돈

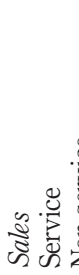

๓

$\infty$

क ल

సิ ชิ
足栗

言言究

कृ की

总苜莞

80

苋昰

४ल है.

包

88 중

웜.

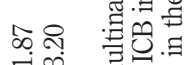

过

过

$\exists$

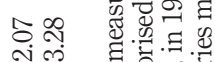

0 . 0

เै จ

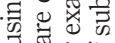

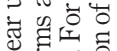

2.

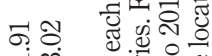

ヨ.

矛合

늘

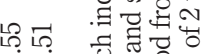

过造

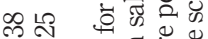

드.

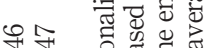

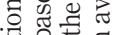

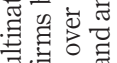

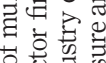

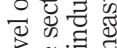
\& 8

\&

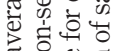

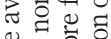
‡苛. 兽

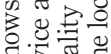
का 플

월 표리

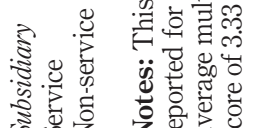

Study based on sales and subsidiaries data

295

Table 5. Industrial analysis based on sales and subsidiaries 
MBR 29,2 the degree of increase varies in the measures used. The number of firms with sales and subsidiaries only in their home-country have decreased over the 18-year time period. Few firms are classified as purely domestic in sales $(13 \%)$. The proportion of firms with domestic subsidiaries is $15 \%$. The number of firms categorised as trans-regional (operations across multiple regions) form the majority whereas global and regional firms are the smallest in proportion, highlighting the "trans-regional" nature of firm operations in the UK. This phenomenon is evident throughout the 18 -year time period. Firm operations continue to be concentrated in the triad regions (Rugman, 2003). Our results show that in recent years, there has been significant growth to non-triad regions. This suggests that firms are expanding their operations beyond their home region and are moving towards a more interregional strategy rather than an intra-regional one. Outward FDI data supports our finding as it suggests a dramatic decline in investments to Organisation for Economic Co-operation and Development countries post 2008 and outflows to Africa have increased from $\$ 1.4 \mathrm{bn}$ in 2008 to $\$ 7.5 \mathrm{bn}$ in 2012 . An overall increase in outward FDI figures over the 18 -year period supports the internationalisation pattern of increasing foreign engagement found in the firm-level analysis of foreign subsidiaries. With a slowdown of global FDI figures since the onset of the global financial crisis, a region-level analysis shows engagement of firms continuing in the traditional triad-region and expanding to non-triad regions.

Second, the conclusions on the growing dispersion of firm operations have strong implications in the area of supply chain literature. New light is shed on the regional vs global nature of supply chains for both upstream and downstream activities over time (Rugman et al., 2009; Verbeke et al., 2016). Oh et al. (2019) highlight the dynamic internationalisation path of upstream and downstream activities of multinational firms. We focus on the geographic spread of upstream (subsidiaries) and downstream (sales) activities across six regions. Our results show the increasing geographic dispersion of both upstream and downstream activities of UK firms. This contributes to the literature on the internationalisation of upstream activities by using non-accounting subsidiaries data. The unique measure of existence of sales and subsidiaries provides useful information regarding the internationalisation patterns that firms tend to follow based on the type of firm activity. There is evidence to support the use of accounting information disclosed by firms in combination with non-accounting primary data. This allows measurement of geographical dispersion of firm operations in a robust manner.

Third, we contribute to the literature on multinationality at both firm-level and industry-level. The industrial analysis shows basic materials and oil and gas are the most multinational and utilities is the least based on both measures. These findings are consistent with Ietto-Gillies (2001) and Rugman and Verbeke (2008) for both service and non-service sector firms. Managers throughout the supply chain can incorporate industry-specific information on internationalisation patterns to identify geographic diversification opportunities.

Finally, our findings suggest that investing in domestic markets provides investors with a portfolio of firms that operate in an increasing number of geographic regions over time. This is crucial for investor awareness and may affect investment decisions of investors as they evaluate the foreign exposure of their portfolios (Cai and Warnock, 2012). Such an indepth and robust analysis at a firm level equips investors to make more informed investment decisions in terms of the location of a firm's operations and their exposure to international factors. This also has strong implications in relation to domestic stock market indices. The domestic market indices used to measure the performance of the home market, in fact contain many MNCs with foreign operations. This may not give an accurate measure of the domestic market, and investors in these indices may have a high degree of international exposure. 
This study provides a detailed and robust analysis of the geographical dispersion of firm activities over time, although it is not without limitations. The analysis of hand-collected subsidiary data for a lengthy time period limited this study to UK listed firms. Considering the depth this data lends to the study of geographical scope of firms, we recommend that the subsidiaries data should be collected for other countries. Extending this analysis to different countries, especially emerging economies, offers significant possibilities for future research focussed on examining the changing patterns of multinationality. The internationalisation levels and paths may be different for some developing countries compared to developed ones. Future research may also investigate the financial performance of firms with different levels of multinationality. This will provide useful information to stakeholders on the firms' financial performance while pursuing regional vs global supply chains. A further limitation may be that we only use existence of sales and subsidiaries data to measure the geographic spread of these activities. It will greatly enrich the debate surrounding firm-level multinationality if subsequent studies examine the nature and size of these activities. This will enable researchers to study how different value chain activities affect the firms' global expansion. Researchers and managers will gain a more rigorous understanding of the international involvement of domestically listed firms. Future work can also focus on the impact of the unique features of the host regions of upstream and downstream activities on the firm's multinationality. This analysis should also be extended to investigate the impact of the COVID-19 pandemic on firm-level internationalisation. This will enable an analysis of the effects of a pandemic on firms' internationalisation strategy. We posit that firms may face challenges while engulfed with uncertainty, and the length of this uncertainty will bring about changes in the global environment. The complex repercussions on internationalisation because of this crisis will be at the centre of future IB research.

\section{References}

Aggarwal, R., Berrill, J., Hutson, E. and Kearney, C. (2011), "What is a multinational corporation? Classifying the degree of firm-level multinationality", International Business Review, Vol. 20 No. 5, pp. 557-577.

Arregle, J.-L., Beamish, P.W. and Hébert, L. (2009), "The regional dimension of MNEs' foreign subsidiary localization", Journal of International Business Studies, Vol. 40 No. 1, pp. 86-107.

Asmussen, C.G. (2009), "Local, regional, or global? Quantifying MNE geographic scope", Journal of International Business Studies, Vol. 40 No. 7, pp. 1192-1205.

Banalieva, E.R. and Santoro, M.D. (2009), "Local, regional, or global? Geographic orientation and relative financial performance of emerging market multinational enterprises", European Management Journal, Vol. 27 No. 5, pp. 344-355.

Bekaert, G., Harvey, C.R., Lundblad, C.T. and Siegel, S. (2011), "What segments equity markets? ”, Review of Financial Studies, Vol. 24 No. 12, pp. 3841-3890.

Benito, G.R.G. and Welch, L.S. (1997), "De-internationalization”, MIR: Management International Review, pp. 7-25.

Berrill, J. (2015), “Are the world's largest firms regional or global?”, Thunderbird International Business Review, Vol. 57 No. 2, pp. 87-101.

Berrill, J. and Hovey, M. (2018), “An empirical investigation into the internationalisation patterns of UK firms", Transnational Corporations Review, Vol. 10 No. 4, pp. 396-408.

Brennan, L., Spencer, L. and Stewart, J. (2018), "Establishing how MNCs are defined: a response to the regional/global debate", Contemporary Issues in International Business, Springer, pp. 233-249.

Cai, F. and Warnock, F.E. (2012), "Foreign exposure through domestic equities", Finance Research Letters, Vol. 9 No. 1, pp. 8-20. 
MBR 29,2

Chadha, P. and Berrill, J. (2016), "An empirical investigation into the internationalization patterns of Japanese firms", Asia Pacific Business Review, Vol. 22 No. 4, pp. 595-611.

Chetty, S. and Campbell-Hunt, C. (2003), "Paths to internationalisation among small-to medium-sized firms: a global versus regional approach", European Journal of Marketing, Vol. 37 Nos 5/6, pp. 796-820.

Chetty, S., Johanson, M. and Martín, O.M. (2014), "Speed of internationalization: conceptualization, measurement and validation”, Journal of World Business, Vol. 49 No. 4, pp. 633-650.

Clark, T. and Knowles, L.L. (2003), "Global myopia: globalization theory in international business", Journal of International Management, Vol. 9 No. 4, pp. 361-372.

Clark, T., Knowles, L. and Hodis, M. (2004), "Global dialogue: a response to the responders in the special globalization issue of JIM", Journal of International Management, Vol. 10 No. 4, pp. 511-514.

Collinson, S. and Rugman, A.M. (2008), "The regional nature of Japanese multinational business", Journal of International Business Studies, Vol. 39 No. 2, pp. 215-230.

Donadelli, M. and Persha, L. (2014), "Understanding emerging market equity risk premia: industries, governance and macroeconomic policy uncertainty", Research in International Business and Finance, Vol. 30, pp. 284-309.

Dunning, J. (1993), Multinational Enterprises and the Global Economy, Addison-Wesley, Wokingham.

Dunning, J.H., Fujita, M. and Yakova, N. (2007), "Some macro-data on the regionalisation/globalisation debate: a comment on the Rugman/Verbeke analysis", Journal of International Business Studies, Vol. 38 No. 1, pp. 177-199.

Flores, R.G. and Aguilera, R.V. (2007), "Globalization and location choice: an analysis of US multinational firms in 1980 and 2000", Journal of International Business Studies, Vol. 38 No. 7 , pp. 1187-1210.

Ghemawat, P. (2003), "Semiglobalization and international business strategy", Journal of International Business Studies, Vol. 34 No. 2, pp. 138-152.

Gupta, A.K., Govindarajan, V. and Wang, H. (2008), The Quest for Global Dominance: Transforming Global Presence into Global Competitive Advantage, John Wiley and Sons.

Ietto-Gillies, G. (2001), "Assessing the degree of internationalization. Some conceptual issues", Workshop paper, Workshop MIUR-ITG, Torino.

Johanson, J. and Vahlne, J.E. (2006), "Commitment and opportunity development in the internationalization process: a note on the Uppsala internationalization process model", Management International Review, Vol. 46 No. 2, pp. 165-178.

Kundu, S.K. and Lahiri, S. (2015), "Turning the spotlight on service multinationals: new theoretical insights and empirical evidence", Journal of International Management, Vol. 21 No. 3, pp. 215-219.

Makhija, M.V., Kim, K. and Williamson, S.D. (1997), "Measuring globalization of industries using a national industry approach: empirical evidence across five countries and over time", Journal of International Business Studies, Vol. 28 No. 4, pp. 679-710.

Marcelo, J.L.M., Quirós, J.L.M. and Martins, J.L. (2013), "The role of country and industry factors during volatile times", Journal of International Financial Markets, Institutions and Money, Vol. 26, pp. 273-290.

Mentzer, J.T., DeWitt, W., Keebler, J.S., Min, S., Nix, N.W., Smith, C.D. and Zacharia, Z.G. (2001), "Defining supply chain management", Journal of Business Logistics, Vol. 22 No. 2, pp. 1-25.

Mullen, C. and Berrill, J. (2015), "Minoritynationals: an empirical analysis of the concentration of geographic sales expansion in MNCs", Multinational Business Review, Vol. 23 No. 4, pp. 277-305.

O'Hagan-Luff, M. and Berrill, J. (2016), "US firms-how global are they? A longitudinal study", International Review of Financial Analysis, Vol. 44, pp. 205-216.

Oehler, A., Wendt, S. and Horn, M. (2017), “Are investors really home-biased when investing at home?”, Research in International Business and Finance, Vol. 40, pp. 52-60. 
Oh, C.H. (2009), "The international scale and scope of European multinationals", European Management Journal, Vol. 27 No. 5, pp. 336-343.

Oh, C.H. and Contractor, F.J. (2012), "The role of territorial coverage and product diversification in the multinationality-performance relationship", Global Strategy Journal, Vol. 2 No. 2, pp. 122-136.

Oh, C.H., Kim, M. and Shin, J. (2019), "Paths and geographic scope of international expansion across industries", International Business Review, Vol. 28 No. 3, pp. 560-574.

Osegowitsch, T. and Sammartino, A. (2008), "Reassessing (home-) regionalisation", Journal of International Business Studies, Vol. 39 No. 2, pp. 184-196.

Peng, M.W. and Delios, A. (2006), "What determines the scope of the firm over time and around the world? An Asia Pacific perspective", Asia Pacific Journal of Management, Vol. 23 No. 4, pp. 385-405.

Regnér, P. and Zander, U. (2014), "International strategy and knowledge creation: the advantage of foreignness and liability of concentration”, British Journal of Management, Vol. 25 No. 3, pp. 551-569.

Rugman, A.M. (2003), "Regional strategy and the demise of globalization", Journal of International Management, Vol. 9 No. 4, pp. 409-417.

Rugman, A.M. and Brain, C. (2003), "Multinational enterprises are regional, not global", Multinational Business Review, Vol. 11 No. 1, pp. 3-12.

Rugman, A.M. and Oh, C.H. (2011), "Methodological issues in the measurement of multinationality of US firms", Multinational Business Review, Vol. 19 No. 3, pp. 202-212.

Rugman, A.M. and Oh, C.H. (2010), "Does the regional nature of multinationals affect the multinationality and performance relationship? ”, International Business Review, Vol. 19 No. 5 , pp. 479-488.

Rugman, A.M. and Oh, C.H. (2013), "Why the home region matters: location and regional multinationals", British Journal of Management, Vol. 24 No. 4, pp. 463-479.

Rugman, A.M. and Verbeke, A. (2004), "A perspective on regional and global strategies of multinational enterprises", Journal of International Business Studies, Vol. 35 No. 1, pp. 3-18.

Rugman, A.M. and Verbeke, A. (2008), "A new perspective on the regional and global strategies of multinational services firms", Management International Review, Vol. 48 No. 4, pp. 397-411.

Rugman, A.M., Li, J. and Oh, C.H. (2009), “Are supply chains global or regional? ”, International Marketing Review, Vol. 26 Nos 4/5, pp. 384-395.

Rugman, A.M., Oh, C.H. and Lim, D.S.K. (2012), "The regional and global competitiveness of multinational firms", Journal of the Academy of Marketing Science, Vol. 40 No. 2, pp. 218-235.

UNCTAD (2015), "World investment report 2015: reforming international investment governance", United Nations Publications Customer Service, p. 253.

Verbeke, A., Kano, L. and Yuan, W. (2016), "Inside the regional multinationals: a new value chain perspective on subsidiary capabilities", International Business Review, Vol. 25 No. 3, pp. 785-793.

Yip, G.S. (2002), “Global strategy. in a world of nations”, Sloan Management Review, Vol. 31 No. 1, p. 35.

\section{Corresponding author}

Pearlean Chadha can be contacted at: pearlean.chadha@tudublin.ie

For instructions on how to order reprints of this article, please visit our website:

www.emeraldgrouppublishing.com/licensing/reprints.htm

Or contact us for further details: permissions@emeraldinsight.com 